\title{
Synthesis of Zr-Si-O-N Phases by Carbonitriding Reaction. Characterization of Crystalline Phases Using the Rietveld Method
}

\author{
A.D. Mazzoni ${ }^{*}$, M.S. Conconi, E.F. Aglietti \\ Centro de Tecnología de Recursos Minerales y Cerámica, Cno. Centenario y 506 \\ C.C. 49 (B1897ZCA) M.B. Gonnet - Buenos Aires, Argentina
}

Received: November 26, 2000; Revised: April 20, 2001

\begin{abstract}
Zirconium compounds are of great interest for ceramic application due to their excellent thermal and mechanical properties. Zirconium phases of the system $\mathrm{Zr}-\mathrm{O}-\mathrm{C}-\mathrm{N}$ were obtained using carbonitriding reactions of zircon mineral $\left(\mathrm{ZrO}_{2} \cdot \mathrm{SiO}_{2}\right)$, under different reaction conditions. The reaction products were studied by X-ray diffraction (XRD) using the Rietveld method. Silicon was employed as internal standard. Zirconium compounds formed were $\mathrm{m}-\mathrm{ZrO}_{2}$ (monoclinic), $\beta$ "-zirconium oxynitride and a cubic $\mathrm{Zr}(\mathrm{C}, \mathrm{N}, \mathrm{O})$ phase whose lattice parameter $\mathrm{a}_{\mathrm{o}}$ depends on the composition. The crystallite sizes of the three zirconium phases were determined also by XRD. The minority phases present are the ones of the Si-O-N-C system. The reaction conditions employed allows to obtain reaction products with low or without silicon content.
\end{abstract}

Keywords: $\operatorname{ZrC}, \mathrm{ZrN}, \beta$ ”-phases, Rietveld

\section{Introduction}

Structural ceramics based on nitrides, oxynitrides and carbides are of great scientific as well as technological interest due to their good physical and chemical properties. Among these ceramics, composites of the type $\mathrm{ZrN}$ $\mathrm{Si}_{2} \mathrm{~N}_{2} \mathrm{O}, \mathrm{ZrO}_{2}-\mathrm{Si}_{2} \mathrm{~N}_{2} \mathrm{O}$, etc. are found ${ }^{1}$. There exist several ways to obtain these composites employing different routes and reacting systems such as $\mathrm{Si}_{3} \mathrm{~N}_{4}-\mathrm{ZrSiO}_{4}-\mathrm{N}_{2}, \mathrm{Si}_{-} \mathrm{ZrSiO}_{4}-$ $\mathrm{N}_{2}$, etc. ${ }^{1}$. Carbonitriding reactions of minerals (reduction with carbon and simultaneous nitriding) constitute an interesting way to obtain oxynitride and oxycarbide compounds. Furthermore, these reactions have a great flexibility since it is possible to obtain a wide variety of products depending on the raw materials used as well as on the reaction conditions employed ${ }^{2,3}$. Using $\mathrm{ZrSiO}_{4}$ as starting raw compound, phases like $\mathrm{ZrN}, \mathrm{ZrC}, \mathrm{ZrO}_{2}, \mathrm{Zr}(\mathrm{C}, \mathrm{N}, \mathrm{O})$ can be obtained.

The Rietveld method allows to characterize properly these phases by XRD. This method was developed by Hugo Rietveld in $1969^{4}$, in order to refine crystalline structures using data of neutron diffraction. At the present time, it is used to perform analysis of structure and crystalline defects, reticular parameter measurement and quantitative analysis with $\mathrm{X}$ - ray diffraction data.
The method consists in adjusting point by point the experimental intensities corresponding to the complete spectrum with the calculated intensities according to a determined model of crystal structure, diffraction optical effects, instrumental factors and other characteristics of the sample. Parameters included in the model are refined until the best least squares fitting is obtained between the entire observed powder diffraction pattern and the entire calculated pattern.

In this work, zirconium rich phases obtained from the $\mathrm{ZrSiO}_{4}$ carbonitriding were studied and characterized by the use of the Rietveld method.

\section{Materials and Methods}

Raw materials used were: $\mathrm{ZrSiO}_{4}$ from Germany (Table 1) and carbon black (carbon 97\%, ash 1\%, volatiles $2 \%$ and a specific surface area BET $=45 \mathrm{~m}^{2} / \mathrm{g}$ ). Both powders have $\mathrm{d}_{50} 10 \mu \mathrm{m}$. The $\mathrm{N}_{2}$ used contained less than $5 \mathrm{ppm}$ of $\mathrm{O}_{2}$ and $\mathrm{H}_{2} \mathrm{O}$.

Samples were prepared by wet mixing of the calculated amounts of reactives, then, they were dried and pressed at $39 \mathrm{MPa}$ into cylinders of $2 \mathrm{~mm}$ in height and $10 \mathrm{~mm}$ in diameter. The samples used were called Z1 (11.6\% of C), Z2 (20.8\% of C), Z3 (24.8\% of C) and Z4 (33.3\% of C). 
Table 1. Chemical composition of $\mathrm{ZrSiO}_{4}$.

\begin{tabular}{lccccccc}
\hline & $\mathrm{SiO}_{2}$ & $\mathrm{ZrO}_{2}$ & $\mathrm{HfO}_{2}$ & $\mathrm{Al}_{2} \mathrm{O}_{3}$ & $\mathrm{TiO}_{2}$ & $\mathrm{Fe}_{2} \mathrm{O}_{3}$ & $\mathrm{P}_{2} \mathrm{O}_{5}$ \\
\cline { 2 - 8 } $\mathrm{Wt}(\%)$ & 32.60 & 64.70 & 1.30 & 0.90 & 0.11 & 0.05 & 0.10 \\
\hline
\end{tabular}

Reactions were performed in a horizontal alumina reactor with $\mathrm{N}_{2}$ gas flowing through it. The pressure used was $0.05 \mathrm{Mpa}$ above the atmospheric pressure and the flow was $0.5 \mathrm{l} / \mathrm{min}$ (linear flow rate: $3 \mathrm{~cm} \cdot \mathrm{s}^{-1}$ ). Experiments were carried out within the range 1350 to $1650{ }^{\circ} \mathrm{C}$ with reaction times of $120 \mathrm{~min}$ and the temperature slopes were $10^{\circ} \mathrm{C} / \mathrm{min}$, upward as well as downward. The $\mathrm{N}_{2}$ flow was kept during cooling up to $200^{\circ} \mathrm{C}$.

Crystalline phases were characterized by $\mathrm{X}$ ray diffraction with a Philips 3020 Goniometer with PW 3710 controller, $\mathrm{Cu}-\mathrm{K} \alpha$ radiation and $\mathrm{Ni}$ filter at $40 \mathrm{kv}-20 \mathrm{~mA}$. The scanning were made at room temperature between $10^{\circ}$ and $75^{\circ}$ in $2 \theta$ with step size of $0.02^{\circ}$ and a step counting time of $2 \mathrm{~s}$ Some samples were scanned with $40 \mathrm{kv}-30 \mathrm{~mA}$ and a step counting time of $4 \mathrm{~s}$ The set of divergence, receiving and scattering slits were $1^{\circ}, 0.2^{\circ}, 1^{\circ}$ and no monochromator was used.

Fullprof program ${ }^{5}$, which is a multipurpose profile-fitting program (including Rietveld refinement) was used to calculate the lattice parameters. The starting crystallographic data were taken from literature ${ }^{6,7,8}$. The refining sequence began with the adjustment of the shift in $2 \theta$ due to vertical specimen displacement and the background. To do this, elemental $\mathrm{Si}$ was added to the samples as internal standard. The background was adjust with a fourth order polynomial. Then, the scale factors, the cell constants, the parameters $\mathrm{U}, \mathrm{V}$ and $\mathrm{W}$ for the calculation of full-width-athalf-maximum (FWHM), the mixing coefficient $\eta$ of the pseudo Voight profile function and the parameters of the March function for preferred orientation correction for each phase were refined sequentially.

In the case of $\beta$ " phase ( $\mathrm{Zr}$ oxynitride), the atomic positions have not been defined exactly, and consequently the structure factors of the diffraction lines cannot be calculated. For cases in which the structure factors cannot be generated from the atomic positions, the Fullprof program uses the space group and the cell constants to generate all the permitted diffraction lines, fitting their intensities according to the observed intensities of the present Bragg lines. This mode of fitting the calculated intensities is called Profile Matching and permits to refine the cell constants and the peak positions of any crystalline phase.

Quantitative analysis of the crystalline phases were carried out employing the external standard method. The standard samples for $\mathrm{m}-\mathrm{ZrO}_{2}, \mathrm{SiC}$ and silicon oxinitrides were pure commercial compounds. $\operatorname{The} \operatorname{Zr}(\mathrm{C}, \mathrm{O}, \mathrm{N})$ standard was synthesized by the authors, through $\mathrm{ZrO}_{2}$ and carbon reaction in nitrogen atmosphere. The $\beta$ " standard was a binary mixture of $\mathrm{m}-\mathrm{ZrO}_{2}(45.0$ wt. $\%)$ and $\beta$ " oxynitride $(55.0 \mathrm{wt}$ \% \%) synthesized by the authors.

The crystallite sizes of cubic $\mathrm{Zr}(\mathrm{C}, \mathrm{N}, \mathrm{O})$ and monoclinic $\mathrm{ZrO}_{2}$ compounds were determined on the (200) and (111) peaks respectively, using the Scherrer equation and the PC-APD (PW 1877) Analytical Powder Diffraction Software, Version 3.6. Weight losses were measured by weighing the samples before and after the reaction process.

\section{Results and Discussion}

The following reactions are a description of the observed phenomena, taking into account the thermal behavior of $\mathrm{ZrSiO}_{4}$ (it decomposes at $\mathrm{T}>1600^{\circ} \mathrm{C}$ ).

$$
\begin{aligned}
& 2 \mathrm{ZrSiO}_{4}+3 \mathrm{C}+\mathrm{N}_{2} \rightarrow \mathrm{Si}_{2} \mathrm{~N}_{2} \mathrm{O}+2 \mathrm{ZrO}_{2}+3 \mathrm{CO} \\
& 2 \mathrm{ZrSiO}_{4}+\mathrm{aC}+\mathrm{bN}_{2} \rightarrow \\
& \mathrm{Si}_{2} \mathrm{~N}_{2} \mathrm{O}+2 “ \mathrm{Zr}(\mathrm{C}, \mathrm{N}, \mathrm{O}) "+\mathrm{cCO} \\
& 3 \mathrm{ZrSiO}_{4}+\mathrm{dC}+\mathrm{eN}_{2} \rightarrow \\
& 3 \text { “ } \mathrm{Zr}(\mathrm{C}, \mathrm{N}, \mathrm{O}) \text { ” }+\mathrm{Si}_{3} \mathrm{~N}_{4}+\mathrm{fCO} \\
& \mathrm{ZrSiO}_{4}+\mathrm{gC} \rightarrow \text { " } \mathrm{Zr}(\mathrm{C}, \mathrm{N}, \mathrm{O}) \text { " }+\mathrm{SiC}+\mathrm{hCO}
\end{aligned}
$$

Where: a, b, c, d, e, f, g, h are stoichiometric coefficients produced by the variable $\mathrm{Zr}(\mathrm{C}, \mathrm{N}, \mathrm{O})$ composition.

Figure 1 shows the pseudoternary phase diagram "ZrO$\mathrm{ZrN}-\mathrm{ZrC}$ " proposed by K. Constant et al. ${ }^{9}$ The monophasic zone below the line $\mathrm{ZrC}_{0.45} \mathrm{O}_{0.5}-\mathrm{ZrN}_{0.65} \mathrm{O}_{0.35}$ corresponds to the $\operatorname{Zr}(\mathrm{C}, \mathrm{N}, \mathrm{O})$ phase, which has variable amounts of the four elements $(\mathrm{Zr}, \mathrm{C}, \mathrm{O}, \mathrm{N})$.

The $\operatorname{Zr}(\mathrm{C}, \mathrm{N}, \mathrm{O})$ phase has a cubic crystalline structure (S.G.: Fm3m (225)) similar to that of the phases: $\mathrm{ZrN}$ (JCPDS card $\mathrm{N}^{\circ} 35-753$ ); ZrC (JCPDS card $\mathrm{n}^{\circ} 19-1487$ )

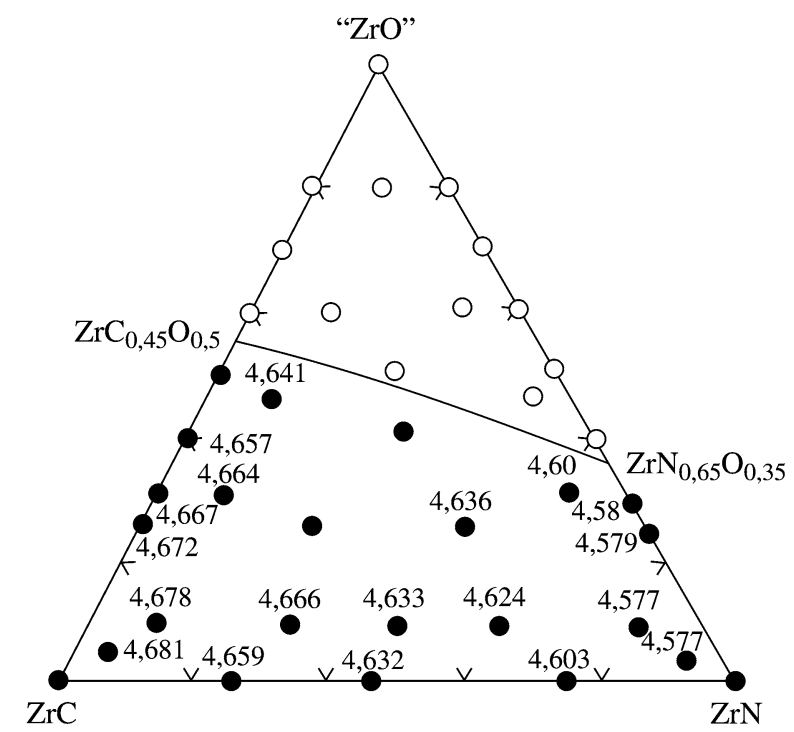

Figure 1. Pseudoternary phase diagram of the "ZrO-ZrN-ZrC" system. The cell parameters of $\operatorname{Zr}(\mathrm{C}, \mathrm{N}, \mathrm{O})$ phases are indicated as: $(\bullet)$ monophase zone and $(\mathrm{O})$ polyphase zone. 
and the calculated for the "ZrO" (JCPDS card n ${ }^{\circ} 20-684$ ). The cell constant $\mathrm{a}_{0}$ of $\mathrm{Zr}(\mathrm{C}, \mathrm{N}, \mathrm{O})$ changes between 4.570 and $4.692 \AA$ A. In Fig. 1, the numerical values correspond to the $\mathrm{a}_{\mathrm{o}}$ values determined by $\mathrm{K}$.

The $\operatorname{Zr}(\mathrm{C}, \mathrm{N}, \mathrm{O})$ phases (Fig. 2) appear in the three samples with higher carbon content and their amount tend to be higher with the increase of temperature and carbon content. The $\operatorname{Zr}(\mathrm{C}, \mathrm{N}, \mathrm{O})$ phases are the principal phases formed at temperatures higher than $1450{ }^{\circ} \mathrm{C}$. The use of the Rietveld method permits to determine their lattice constants. In Fig. 3 the diffraction pattern of the $\mathrm{Z} 4$ at $1500^{\circ} \mathrm{C}$ is shown. The principal phase formed is $\mathrm{Zr}(\mathrm{C}, \mathrm{N}, \mathrm{O})$, accompanied with silicon (internal standard), silicon nitride and zircon. Traces of $\mathrm{Hf}$ oxynitride (PDF Card $\mathrm{n}^{\circ}$ 39-0520) were also formed.

In many samples, the phases $\mathrm{Zr}(\mathrm{C}, \mathrm{N}, \mathrm{O})$ show an excessive width of its XRD peaks and unfolding (Fig. 4).

To obtain a good fitting with the Rietveld method it is necessary to employ two phases of the $\operatorname{Zr}(\mathrm{C}, \mathrm{N}, \mathrm{O})$ system, one of them with an $\mathrm{a}_{0}$ between $4.577 \AA$ and $4.582 \AA$ and the other with an $\mathrm{a}_{0}$ higher than $4.600 \AA$. The use of these two phases allows to have $R_{\text {Bragg }}$ values near 2.5 for those

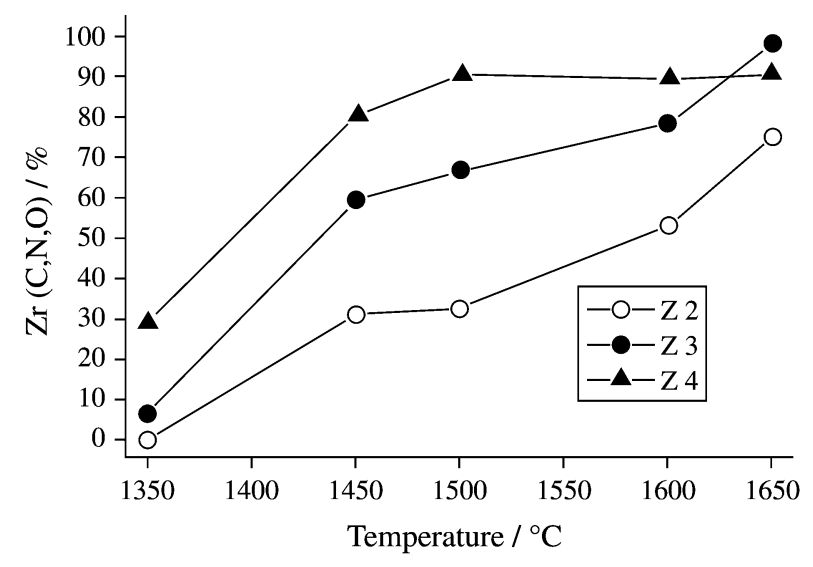

Figure 2. Evolution of the $\mathrm{Zr}(\mathrm{C}, \mathrm{N}, \mathrm{O})$ phase with temperature and carbon content. (Reaction time: $120 \mathrm{~min}$ ).

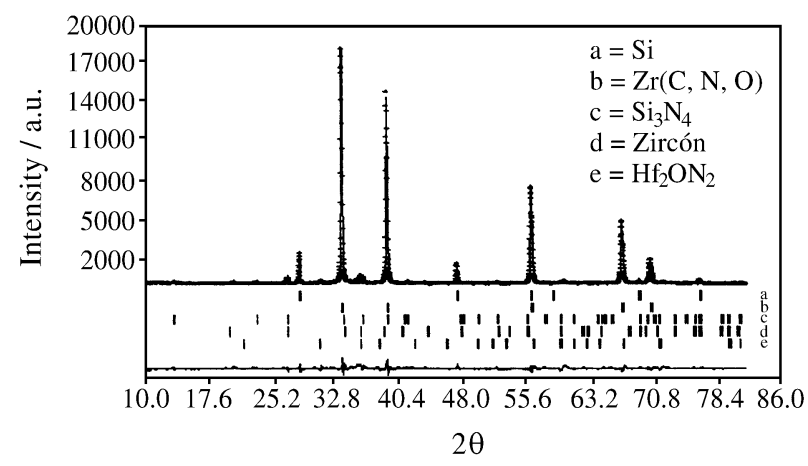

Figure 3. Rietveld analysis for sample $\mathrm{Z} 4$ treated at $1500{ }^{\circ} \mathrm{C}$. (Reaction time: $120 \mathrm{~min})$.

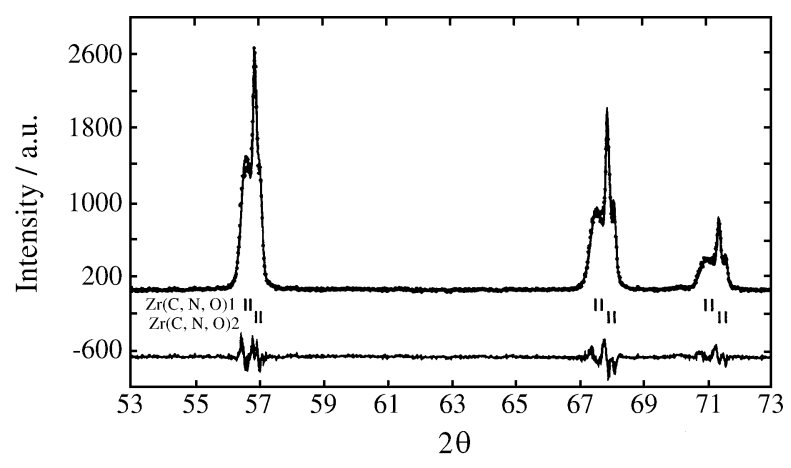

Figure 4. Diffractogram showing the unfolding of the $\operatorname{Zr}(\mathrm{C}, \mathrm{N}, \mathrm{O})$ phase.

phases. The $\mathrm{R}_{\exp }$ are between 4.53 and 5.67 and the $\mathrm{R}_{\mathrm{wp}}$ are between 10.9 and 16.0.

The values of the $a_{0}$ parameter for both $\operatorname{Zr}(\mathrm{C}, \mathrm{N}, \mathrm{O})$ phases tend to be higher with the increase of temperature and carbon content, and they are unified in a unique phase with an $a_{0}$ between $4.601 \AA$ and $4.624 \AA$ with values of residuals RBragg, Rexp, Rwp similar to those mentioned in the above paragraph. It is not possible to determine the exact composition of the $\operatorname{Zr}(\mathrm{C}, \mathrm{N}, \mathrm{O})$ phase only with the XRD measurements, since different compositions may have the same $a_{0}$ (see Fig. 1). By the XRD technique, N, C and $\mathrm{O}$ cannot be differentiated in spite of using the Rietveld method because of their similar atomic weight. The chemical analysis is difficult to be performed because the $\mathrm{C}+\mathrm{O}+\mathrm{N}$ contents are below $16 \mathrm{wt} . \%$, and for example, the expected oxygen content is lower than $4 \%$. Thus, little composition errors produce a big shift in the phase diagram.

With respect to the crystallite size, these phases show values between 576 and $1800 \AA$ A with a well defined tendency to increase with temperature. Crystallite sizes may be larger because in phases like these ones, where there are wide ranges of solid solutions, peaks tend to widen ${ }^{10,11}$.

Other zirconium phase found is the monoclinic $\mathrm{ZrO}_{2}$. The Rietveld analysis of this phase shows the following average value of the crystal constants: $\mathrm{a}_{0}=5.155 \AA$, $\mathrm{b}_{0}=5.2012 \AA, \mathrm{c}_{0}=5.3252 \AA$ and $\beta=99.158^{\circ}$. These values are near the theoretical ones. $\left(a_{0}=5.1454 \AA, b_{0}=5.2075 \AA\right.$, $\mathrm{c}_{\mathrm{o}}=5.3107 \AA, \beta=99.23^{\circ}$ )

The evolution of the $\mathrm{m}-\mathrm{ZrO}_{2}$ phase as a function of the reaction conditions is shown in Fig. 5. This phase becomes less important when the carbon content increases. Thus, in $\mathrm{Z} 2$ to $\mathrm{Z} 4$ samples a continuous decrease of $\mathrm{ZrO}_{2}$ with temperature is observed, related with the increase in the $\mathrm{Zr}(\mathrm{C}, \mathrm{N}, \mathrm{O})$ content. The $\mathrm{Z} 1$ sample presents a different behavior with respect to the other samples, with an initial growth of the $\mathrm{ZrO}_{2}$ and then a decrease of this phase above $1600{ }^{\circ} \mathrm{C}$.

Also, $\beta$ type zirconium oxynitride phases $\mathrm{ZrO}_{2-2 x} \mathrm{~N}_{4 x} / 3$ were detected ${ }^{12}$. These phases are called $\beta, \beta$, and $\beta$ " depending on their composition. The differences between 


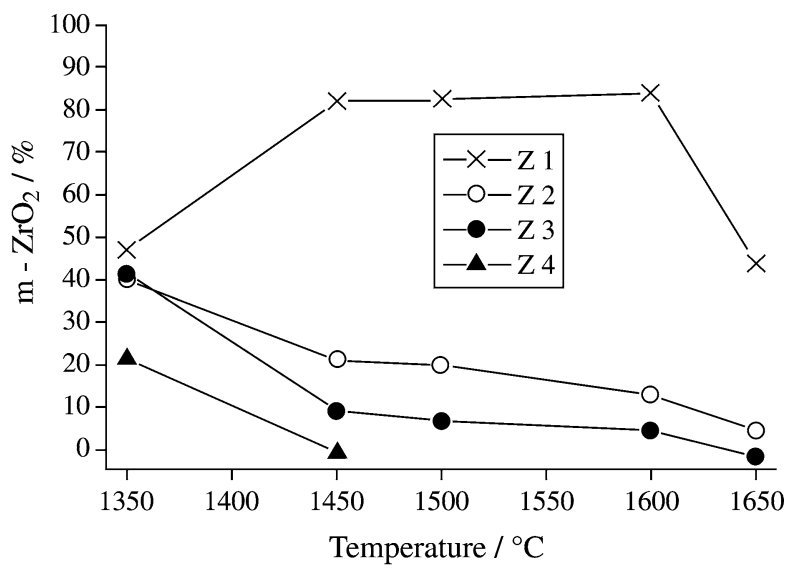

Figure 5. Evolution of the $\mathrm{m}-\mathrm{ZrO}_{2}$ with temperature and carbon content. (Reaction time: $120 \mathrm{~min}$ ).

the $\beta$ phases are little, mainly between $\beta$ ' and $\beta$ ". The Rietveld analysis made on the $\beta$ type phases showed that the $\beta$ " phase fitted very well the diffractogram obtained (Fig. 6). In Table 2, the experimental measurements are compared with the $\beta$ ' phase (PDF card 48-1637) and the $\beta$ ", phase peaks calculated with de Profile Matching mode of the Fullprof program. This table shows the position of the diffraction lines of these phases between 10 and $25^{\circ}$. The

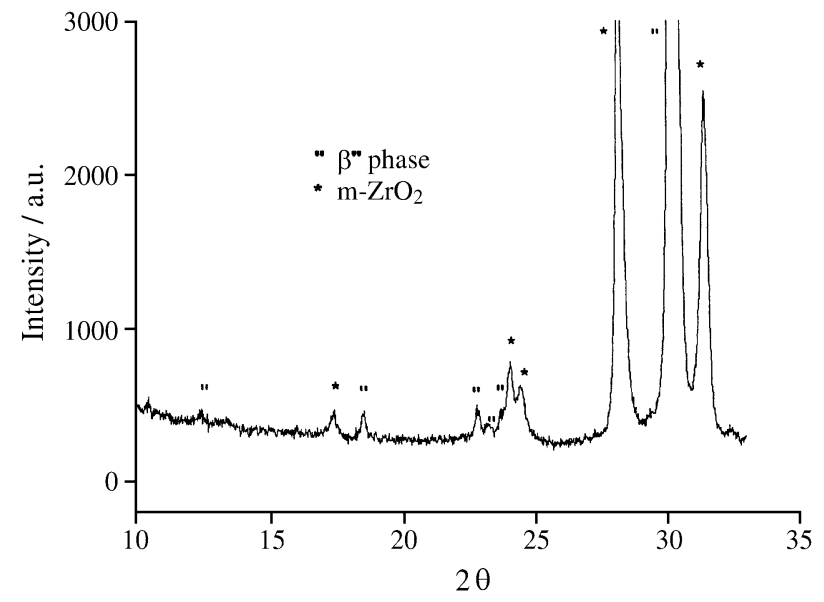

Figure 6. Diffractogram of the $\beta$ " phase between $10^{\circ}$ and $25^{\circ}$.

Table 2. Positions of diffraction lines for $\beta$ phases.

\begin{tabular}{lll}
\hline$\beta$, & Typical sample & $\beta^{\prime \prime}$ \\
\hline $2 \theta(\mathrm{d})$ & $2 \theta(\mathrm{d})$ & $2 \theta(\mathrm{d})$ \\
$11.80(7.49)$ & & \\
& $12.4(7.13)$ & $12.24(7.22)$ \\
$18.53(4.78)$ & $18.53(4.78)$ & $18.55(4.78)$ \\
$22.94(3.88)$ & $22.88(3.89)$ & $22.91(3.88)$ \\
& $23.20(2.83)$ & $23.29(3.81)$ \\
$23.73(3.75)$ & $23.75(3.74)$ & $23.75(3.75)$ \\
\hline
\end{tabular}

relative intensities of the diffraction peaks were also in agreement with those reported by Lerch ${ }^{12}$ for the $\beta$ " phase. To prove this, samples with higher $\beta$ " phase content were analyzed by XRD using long periods of measurement (scanned with $40 \mathrm{kv}-30 \mathrm{~mA}$ and a step counting time of $4 \mathrm{~s})$.

The formation of the $\beta$ " phase could be expected in our working conditions ${ }^{12}$. The unit cell parameters measured were the following: "ao" between $9.459-9.552 \AA$ $\left[9.554 \AA^{12}\right]$ and "c" between $44.33-44.35 \AA$ [44.11 $\left.\AA^{12}\right]$. Thus, this phase will be called henceforth $\beta$ ".

The XRD peaks that allow to differentiate between the $\beta$ ' and $\beta$ " (Table 2) are quite small, near $1 / 1000$ of the more intense peaks. These peaks are visible only in samples with a high content of $\beta$ phases. The high intensity peaks of the $\beta$ phases appear in all the samples. These peaks are very similar to that of the cubic- $\mathrm{ZrO}_{2}$. Experiments carried out using argon instead of nitrogen showed that "cubic- $\mathrm{ZrO}_{2}$ peaks" were not detected; this fact confirms that they are oxynitride compounds. The Rietveld analysis of "cubic$\mathrm{ZrO}_{2}$ peaks" of the $\beta$ " phase is in accord with a cubic crystal structure with $\mathrm{a}_{0}$ between 5.100 and $5.112 \AA$ depending on the sample studied. This is in agreement with the phase called "nitrogen stabilized cubic zirconia" ("N- $\mathrm{ZrO}_{2}$ ") found by Claussen et al. ${ }^{13}$. Other researchers ${ }^{14-17}$ established that " $\mathrm{N}-\mathrm{ZrO}_{2}$ " phases are $\beta$-type zirconium oxynitrides with the following composition: $\mathrm{ZrO}_{2-2 X} \mathrm{~N}_{4 X / 3}$.

Figure 7 shows the evolution of the $\beta$ " phase with temperature. The $\beta$ " phase appears in important amounts in $\mathrm{Z} 2$ sample and in lower proportion in $\mathrm{Z} 3$ between $1350{ }^{\circ} \mathrm{C}$ and $1600{ }^{\circ} \mathrm{C}$. In $\mathrm{Z} 4$ sample, the $\beta$ " phase appears up to $1450^{\circ} \mathrm{C}$ while in $\mathrm{Z} 1$ the $\beta$ " phase increases slowly with the temperature increase, showing an important growth at $1650{ }^{\circ} \mathrm{C}$ where the $\beta$ " phase reaches contents higher than $50 \%$.

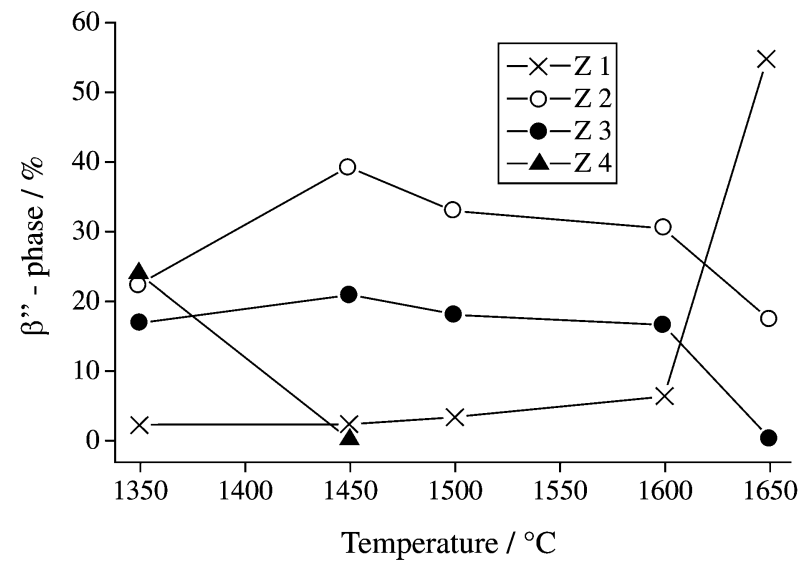

Figure 7. Evolution of the $\beta$ " phase with temperature and carbon content. (Reaction time: $120 \mathrm{~min}$ ). 
Table 3. Mean unit-cell parameters for Silicon phases.

\begin{tabular}{lccc}
\hline Phase & $\mathrm{a}_{\mathrm{O}}$ & $\mathrm{b}_{\mathrm{O}}$ & $\mathrm{c}_{\mathrm{O}}$ \\
\hline$\beta-\mathrm{Si}_{3} \mathrm{~N}_{4}$ & $7.6165(2)$ & & $2.9109(3)$ \\
$\mathrm{Si}_{2} \mathrm{~N}_{2} \mathrm{O}$ & $5.5046(1)$ & $8.8969(3)$ & $4.8538(2)$ \\
$\beta-\mathrm{SiC}$ & $4.3619(3)$ & & \\
\hline
\end{tabular}

Silicon phases formed were: $\mathrm{Si}_{2} \mathrm{~N}_{2} \mathrm{O}, \mathrm{Si}_{3} \mathrm{~N}_{4}$ and $\mathrm{SiC}$. Using the Rietveld analysis, the lattice parameters of these phases were determined (Table 3 ). These values are in agreement with those of other authors 8,18 .

Silicon phases were not formed in $\mathrm{Z1} . \mathrm{Si}_{2} \mathrm{~N}_{2} \mathrm{O}$ was found as principal phase in $\mathrm{Z} 2$ and $\mathrm{Z} 3$. In $\mathrm{Z} 4$ a mix of $\mathrm{SiC}$ and $\mathrm{Si}_{3} \mathrm{~N}_{4}$ was found, but always in lower amounts than the expected ones using stoichiometric calculation. This phenomenon is produced by silicon loss as it is explained in the following reactions:

$$
\begin{aligned}
& \mathrm{ZrSiO}_{4}+\mathrm{C} \rightarrow \mathrm{ZrO}_{2}+\mathrm{SiO}_{(\mathrm{g})}+\mathrm{CO}_{(\mathrm{g})} \\
& \mathrm{SiO}_{2}+\mathrm{C} \rightarrow \mathrm{SiO}_{(\mathrm{g})}+\mathrm{CO}_{(\mathrm{g})}
\end{aligned}
$$

This is confirmed by the high weight loss, higher than the loss expected for the reactions (A)-(D).

\section{Conclusions}

- The carbonitriding of zircon generates $\mathrm{Zr}$-phases corresponding to the "ZrO-ZrN-ZrC" system together with silicon oxynitrides or oxycarbides as secondary phases.

- It is possible to obtain $\mathrm{Zr}(\mathrm{C}, \mathrm{N}, \mathrm{O})$ and/or $\mathrm{Zr}$-oxynitrides of the $\beta$ " type regulating the reaction conditions.

- The Rietveld method permitted to characterize the structure of Zr-phases obtained by the carbonitriding of zircon.

- The $\mathrm{SiO}_{(\mathrm{g})}$ loss is an important phenomenon that decreases the silicon content in the reaction products.

- Using controlled reaction conditions allow to obtain products with very low or without silicon in their composition.

\section{References}

1. Jack, K.H. Ceramic toward. The 21 st. Century, The Ceramic Society of Japan, Tokyo, p.465, 1991.

2. Mazzoni, A.D. Estudio de las reacciones de carbonitruración de arcillas caoliníticas. Obtención de $\beta$ 'Sialons, Tesis Univ. Nac. La Plata, 1992.

3. Mazzoni, A.D; Aglietti, E.F.; Pereira, E. Carbonitriding of clay: Relation between the weight loss and crystalline phases during reaction. J. Am. Ceram. Soc, v. 76, n. 9 , p. $2337,1993$.
4. Young R.A. The Rietveld Method, IUCr, Oxford University Press, NY, USA,1993.

5. Rodriguez-Caravajal. Abstracts of the Satellite Meeting on Powder Diffraction of XV Congress of the IUCr. Toulouse, France, p. 127,1990.

6. Howard, C.J.; Hill, R.J.; Reichert, B.E. Structures of $\mathrm{ZrO}_{2}$ Polymorphs at Room Temperature by HighResolution Neutron Powder Diffraction. Acta Crystallographica, v. 44, p. 116-120, 1988.

7. Hazen, R.M; Finger, L.W. Crystal structure and Compressibility of Zircon at High Pressure. American Mineralogist, v. 64, p. 196-201, 1979.

8. Wyckoff, R.W.G. Crystal Structures. Interscience, New York, 1963.

9. Constant, K., Kieffer, R.; Ettmayer, P. Uber das pseudoternare system $\mathrm{ZrO}-\mathrm{ZrN}-\mathrm{ZrC}$. Monatshefte fur Chemie, v. 106, p. 823, 1975.

10. Mazzoni, A.D. Progressive phase changes during the reaction of "clay-Al-N2" and "mullite-Al-N2" in the Si-Al-O-N system. Materials Chemistry and Physics, v. 43, p. 38, 1996.

11. Mazzoni, A.D.; Aglietti, E.F. Mechanism of the carbonitriding reaction of $\mathrm{SiO}_{2}-\mathrm{Al}_{2} \mathrm{O}_{3}$ minerals in $\mathrm{Si}$ - $\mathrm{Al}$ O-N system. Appl. Clay Sci., v. 12, p. 447, 1998.

12. Lerch, M. Nitridation of Zirconia. J. Am. Ceram. Soc., v. 79, p. 2641, 1996.

13. Claussen, N.; Wagner, R.; Gaucker, L.J.; Petzow, G. Nitride - stabilized cubic zirconia. J. Am. Cer. Soc., v. 61, p. 369, 1978.

14. Weiss, J.; Gauckler, L.J.; Lukas, H.L.; Petzow, G.; Tien, T.Y. Determination of phase equilibria in the system $\mathrm{Si}-\mathrm{Al}-\mathrm{Zr} / \mathrm{N}-\mathrm{O}$, by experiment and thermodynamic calculation. J. Mater. Sci., v. 16, p. 2997, 1981.

15. Van Tendeloo, G.; Thomas, G. Electron Microscopy investigation of the $\mathrm{ZrO}_{2}-\mathrm{ZrN}$ system. Acta Metal., v. 31, p. 1611, 1983.

16. Lerch, M., Krumeich, F.; Hock, R. Diffusion controlled formation of $\beta$ type phases in the system $\mathrm{ZrO}_{2}-$ $\mathrm{Zr}_{3} \mathrm{~N}_{4}$. Solid State Ionics, v. 95, p. 87, 1997.

17. M. Lerch, H. Boysen and P.G. Radaelli. High temperature Neutron Scattering investigation of the $\beta$ ' phase in the Mg-ZrO-N system. J. Phys. Chem. Solids, v.58, p. 1557, 1997.

18. Drestedt, I.; Brosset, Acta Chem. Scand., v. 18, p. 1879, 1964. 